\title{
Pyridoxal phosphatase is a novel cancer autoantigen in the central nervous system
}

\author{
AS Bøe ${ }^{*, 1}$, G Bredholt ${ }^{2}$, PM Knappskog ${ }^{2}$, A Storstein ${ }^{3}$, CA Vedeler² and ES Husebye \\ 'Division of Endocrinology, Institute of Medicine, Haukeland University Hospital, N-502I Bergen, Norway; ${ }^{2}$ Center for Medical Genetics and Molecular \\ Medicine, Haukeland University Hospital, Nonway; ${ }^{3}$ Department of Neurology, Haukeland University Hospital, N-502I Bergen, Norway
}

\begin{abstract}
Autoantibodies against many proteins are common in sera from patients with various types of cancer. These antibodies are sometimes involved in the development of conditions associated with cancer, such as paraneoplastic neurologic disorders. We used a human brain cDNA expression library and serum from a paraneoplastic neurologic disorder patient to search for new autoantigens in the nervous system. Pyridoxal phosphatase was identified as a novel autoantigen. Expression studies showed that pyridoxal phosphatase was strongly expressed in various parts of the central nervous system. Sera contained antibodies against pyridoxal phosphatase in 22 of 243 (9.1\%) patients with lung cancer and eight of I 13 (7.1\%) with other forms of cancer vs two of 88 (2.3\%) healthy control subjects. In addition, 2-4\% of patients with different autoimmune diseases had autoantibodies against pyridoxal phosphatase. None of the antipyridoxal phosphatase-positive patients were known to have a paraneoplastic neurologic disorder. Hence, autoantibodies against pyridoxal phosphatase correlate with cancer but not necessarily with the subset of patients with paraneoplastic neurological disorders although serum from such a patient was used to screen the cDNA library. This study showed that yet another enzyme involved in pyridoxal 5'-phosphate metabolism is an autoantigen. Thus, pyridoxal 5'-phosphate seems to be a common denominator for autoantigens involved in autoimmune diseases.
\end{abstract}

British Journal of Cancer (2004) 91, I508-15|4. doi:I0.1038/sj.bjc.6602 I42 www.bjcancer.com

Published online 28 September 2004

(c) 2004 Cancer Research UK

Keywords: autoimmunity; pyridoxal 5'-phosphate; pyridoxal phosphatase

Antibodies against nontissue specific intracellular or cell-surface proteins are seen in several types of cancer, such as antibodies against p53 (Crawford et al, 1982), oncogene products such as ras (Cheever et al, 1995), cellular proteins such as p62 (Zhang et al, 1999) and cell cycle proteins such as cyclin B1 (Covini et al, 1997). Other malignant conditions are characterised by autoantibodies against tissue-restricted proteins, as seen in patients with paraneoplastic neurologic disorders (PND). These patients produce antibodies and cytotoxic $\mathrm{T}$ cells that target neuron-specific proteins abnormally expressed in non-neuronal tumours causing neuronal injury (Dalmau and Posner, 1997; Bataller and Dalmau, 2003). The pathogenic role of onconeuronal autoantibodies is often unclear. In other cases, such as Lambert-Eaton myasthenic syndrome, antibodies are directly involved in pathogenesis, such as by blocking voltage-gated calcium channels and causing neuromuscular conduction blockade (Lang et al, 1981).

Detection of circulating autoantibodies signals the presence of malignant disease, often at an early stage (Trivers et al, 1995, 1996), and assay of cancer-associated antibodies can be used in diagnosing cancer. Further, an immune response against the tumour should theoretically help in controlling tumour growth. Souza et al (2003) have recently shown that patients with previous autoimmune thyroid disease and well-differentiated thyroid cancer have a better prognosis than those without signs of thyroid autoimmunity.

*Correspondence: Dr A Bøe; E-mail: Anette.Boe@med.uib.no Received I June 2004; revised 7 July 2004; accepted 20 July 2004; published online 28 September 2004
By using serum from a patient with known PND, we screened a human brain cDNA expression library to identify novel cancerrelated or paraneoplastic autoantigens. One of the positive clones was identified as pyridoxal phosphatase (PDXP) (GenBank accession number AY125047 and BC000320) (Jang et al, 2003). This enzyme dephosphorylates pyridoxal $5^{\prime}$-phosphate (PLP), an important cofactor for enzymes involved in vitamin B metabolism and in neurotransmitter biosynthesis.

\section{METHODS AND SUBJECTS}

\section{Subjects}

Sera were obtained from 243 patients with lung cancer, 113 with different other types of cancers, 47 with multiple sclerosis (MS), 47 with type 1 diabetes, 72 with autoimmune Addison's disease or autoimmune polyendocrine syndromes (APS) and 88 healthy blood donors.

\section{Screening of the cDNA expression library}

A human brain $\lambda$ TriplEx cDNA expression library (human brain 5 -Stretch Plus cDNA Library, Clontech, Palo Alto, CA, USA) was screened with serum from a patient with ovarian cancer and paraneoplastic cerebellar degeneration containing Yo antibodies using the method described by Rorsman et al (1995). Briefly, bacteria and the cDNA library were mixed on a Petri dish containing NZY agar. After about $3.5 \mathrm{~h}$ of culture, plaque appeared 
on the dish. Plaques were copied onto a Hybond $\mathrm{C}$ nitrocellulose membrane (Amersham Pharmacia Biotech, Uppsala, Sweden) containing isopropyl- $\beta$-D-thiogalactoside (Sigma-Aldrich, Steinheim, Germany). Sera and secondary alkaline phosphataseconjugated antibodies were added to the filter, followed by 5bromo-4-chloro-3-indolyl phosphate/nitro blue tetrazolium (BioRad, Sundbyberg, Sweden) to detect immune complexes. Positive clones were rescreened until pure isolates were obtained and thereafter sequenced and identified by a BLAST search (http:// www.ncbi.nlm.nih.gov/BLAST). Full-length clones were ordered when needed from the I.M.A.G.E. Consortium (http://image.llnl.gov).

\section{Radioimmunoassay (RIA)}

The full-length coding cDNA was amplified by polymerase chain reaction using a forward linker-primer containing an $N d e \mathrm{I}$ restriction site (5'-GGAATTCCATATGGCGCGCTGCGAGAGGCT$3^{\prime}$ ) and a reverse linker-primer containing a BamHI restriction site ( $5^{\prime}$-GGCGGATCCGGCTCAGTCCTCCAACCCCTCTGTCAA- $3^{\prime}$ ). The cDNA was then ligated into the NdeI and BamHI restriction sites of pET-19b (Novagen Inc., Madison, USA) and expressed as a $10 \times$ His-tag fusion protein in the in vitro TnT transcriptiontranslation coupled (ITT) system from Promega (Promega, Leiden, the Netherlands) in the presence of $\left[{ }^{35} \mathrm{~S}\right]$ methionine (cell labelling grade, Amersham Pharmacia Biotech) and screened by RIA (Falorni et al, 1995). Titre of antibodies was calculated as relative values compared with standard positive and negative controls ((cpm subject $\mathrm{X}-\mathrm{cpm}$ negative standard)/(cpm positive standardcpm negative standard) $\times 1000)$. The 'normal level' of autoantibodies against this protein in sera was estimated by calculating the mean of index values for 88 healthy blood donors and adding 3 standard deviations.

\section{Protein expression and purification}

The protein was expressed as a $10 \times$ His-tag fusion protein by the vector pET19b in the Escherichia coli strain Rosetta (DE3) pLysS (Novagen, Madison, WI, USA). In total, $500 \mathrm{ml}$ of Luria-Bertani medium containing $50 \mu \mathrm{g} \mathrm{ml}^{-1}$ ampicillin was inoculated with $4 \mathrm{ml}$ of an overnight culture of bacteria generated from a single colony of freshly transformed cells and incubated at $37^{\circ} \mathrm{C}$. The bacterial culture was grown at $37^{\circ} \mathrm{C}$, and protein expression was induced with $1 \mathrm{~mm}$ isopropyl- $\beta$-D-thiogalactoside at an optical density at $600 \mathrm{~nm}$ of 0.9 . The cells were harvested $3.5 \mathrm{~h}$ later by centrifugation. Inclusion bodies were purified in the presence of complete, EDTA-free Protease Inhibitor Cocktail Tablets (Roche, Basel, Switzerland) using the B-PER Bacterial Protein Extraction Reagent (Pierce, Rockford, IL, USA) according to the manufacturer's protocol. Inclusion bodies from a $75-\mathrm{ml}$ culture were dissolved in $2 \mathrm{ml}$ of $6 \mathrm{M}$ guanidine- $\mathrm{HCl}, 20 \mathrm{mM} \mathrm{NaH}_{2} \mathrm{PO}_{4}, 500 \mathrm{~mm} \mathrm{NaCl}, \mathrm{pH} 7.8$ before adding $10 \mathrm{ml}$ of $8 \mathrm{M}$ urea, $20 \mathrm{mM} \mathrm{NaH}_{2} \mathrm{PO}_{4}, 500 \mathrm{~mm} \mathrm{NaCl}, \mathrm{pH}$ 7.8 (buffer A). The solution was then centrifuged at $20000 \times \mathrm{g}$ and filtered through a $0.45-\mu \mathrm{m}$ syringe filter followed by nickel chelate chromatography using the ÄKTAprime chromatography system and a 1-ml HiTrap Chelating HP column (Amersham Pharmacia Biotech) under denaturing conditions. Briefly, the solubilised inclusion bodies were loaded onto the column followed by washing with 40 column volumes of buffer A containing $20 \mathrm{~mm}$ imidazol. The protein was eluted at low $\mathrm{pH}$ by exchanging the wash buffer with a buffer containing $8 \mathrm{M}$ urea, $20 \mathrm{mM} \mathrm{NaH}_{2} \mathrm{PO}_{4}, 500 \mathrm{~mm} \mathrm{NaCl}$, $\mathrm{pH} 3.5$ with a gradient from 0 to $100 \%$ over 20 column volumes. The protein purity was evaluated by sodium dodecyl sulfatepolyacrylamide gel elecrophoresis (SDS-PAGE) followed by Coomassie blue staining. The concentration was determined by the Bradford protein assay (BioRad) using bovine serum albumin (BSA) as standard according to the protocol of the manufacturer.

\section{Rabbit PDXP antiserum}

Purified PDXP was dialysed against sterile phosphate-buffered saline (PBS). Two female outbred rabbits were immunised intradermally with about $50 \mu \mathrm{g}$ of purified protein emulsified $1: 1$ in Freund's complete adjuvant. The rabbits were boosted with about $50 \mu \mathrm{g}$ of protein emulsified $1: 1$ in Freund's incomplete adjuvant on days 14, 28, 56 and 86 after the primary immunisation. After reactivity towards the protein antigen was verified by RIA of radiolabelled protein expressed by ITT (described above) and by Western blot (described below), the rabbits were terminally bled on day 96 and serum was collected.

\section{Western blot}

Recombinant PDXP (about $15 \mu \mathrm{g}$ ) was incubated in $4 \times$ sample buffer and $10 \times$ reducing agent and applied to the large well on a 4-12\% NuPAGE MOPS Bis-Tris gel (Invitrogen, Merelbeke, Belgium). The molecule markers used were the high-range rainbow molecular weight marker (Amersham Pharmacia Biotech) for radiolabelled samples and the Seeblue Plus 2 prestained standard (Invitrogen) for nonlabelled samples. The proteins were blotted onto a Hybond P PVDF membrane (Amersham Pharmacia Biotech) and incubated with sera from 24 cancer patients that were positive for anti-PDXP in RIA or immunised rabbit-serum diluted $1: 100$ in blocking buffer (PBS with $4 \%$ fat-free dry milk) and then with alkaline phosphatase-conjugated rabbit anti-human IgG (Sigma-Aldrich) and goat anti-rabbit IgG (Southern Biotechnology, Birmingham, AL, USA), diluted 1:3000 in blocking buffer. The substrate for alkaline phosphatase was 5-bromo-4-chloro-3indolyl phosphate/nitro blue tetrazolium (BioRad).

\section{Immunohistochemistry}

We used autopsy material from a 69-year-old man, otherwise healthy, who had died from sudden cardiac arrest $24 \mathrm{~h}$ previously. Tissue from cerebrum, cerebellum, liver, kidney, spleen, heart, lung and muscle was taken from 2-3 locations in each organ, snap-frozen in isopenthane cooled in liquid nitrogen and stored at $-80^{\circ} \mathrm{C}$ until use. A total of $8 \mu \mathrm{m}$ thick cryostat sections were incubated with the preimmunised or immunised rabbit sera against PDXP diluted 1:100 in PBS and then with Alexa Fluor goat anti-rabbit IgG (Molecular Probes, Eugene, OR, USA) diluted $1: 100$ in PBS. Analysis used a LEICA fluorescence microscope. In some experiments, sections of human brain were stained with rabbit anti-PDXP diluted 1:100 in PBS followed by peroxidaselabelled anti-rabbit antibody and analysis by light microscopy. Tissue sections were incubated without prior fixation, as we experienced that fixation with acetone or formaldehyde prior to primary incubation did not result in enhanced staining.

\section{Northern blot}

In total, $20 \mu \mathrm{g}$ of total RNA from rat cerebellum purified by the RNeasy mini kit (Qiagen, Hilden, Germany), rat brain (Clontech) and of a pool of total RNA from a wide selection of human tissues (Human Reference total RNA; Clontech) were denatured, electrophoresed on a denaturing $1.2 \%$ formaldehyde agarose gel and blotted onto a Hybond $\mathrm{N}$ nylon membrane (Amersham Pharmacia Biotech) by capillary blotting in the presence of saline sodium citrate buffer $(10 \times$ SSC; $1.5 \mathrm{M} \mathrm{NaCl}, 0.15 \mathrm{M}$ sodium citrate, $\mathrm{pH} 7.0)$. The membrane was washed in a buffer containing $1.6 \times$ SSC and $0.2 \mathrm{M}$ Tris- $\mathrm{HCl} \mathrm{pH} 7.2$ and baked at $80^{\circ} \mathrm{C}$ for $15 \mathrm{~min}$, and the RNA was crosslinked to the membrane at $120 \mathrm{~mJ}$ using Stratalinker 1800 UV (Stratagene, La Jolla, CA, USA). Full-length PDXP cDNA $(20 \mathrm{ng})$ was labelled with $4 \mu \mathrm{l}$ of $\alpha_{-}{ }^{32} \mathrm{P}$-dCTP $\left(3000 \mu \mathrm{Ci} \mathrm{mmol}^{-1}\right.$, Perkin-Elmer, Boston, MA, USA) using the Megaprime kit 
(Amersham Pharmacia Biotech) and purified over a Sephadex G-50 (Amersham Pharmacia Biotech). The blot was wetted in $2 \times$ SSC and prehybridised for $1 \mathrm{~h}$ at $65^{\circ} \mathrm{C}$ in $16 \mathrm{ml}$ of hybridisation buffer containing $2 \mathrm{mg} \mathrm{ml}^{-1}$ bovine serum albumin, $2 \mathrm{mg} \mathrm{ml}^{-1}$ Ficoll $400,2 \mathrm{mg} \mathrm{ml}^{-1}$ polyvinylpyrrolidone $\mathrm{K} 25,0.5 \mathrm{M} \mathrm{NaH}_{2} \mathrm{PO}_{4}$, $14 \mathrm{mg} \mathrm{ml}^{-1}$ SDS, $1 \mathrm{~mm}$ EDTA, $5 \mathrm{mg}$ of heat-denatured, sheared salmon sperm DNA (Sigma-Aldrich) and $30 \mu \mathrm{g}$ of heat-denatured human Cot-1 DNA (Invitrogen). The probe was denatured by heat in $1 \mathrm{ml}$ of hybridisation buffer, added to the hybridisation solution used for prehybridisation and incubated with the membrane at $65^{\circ} \mathrm{C}$ overnight. The hybridised membrane was then washed four times at $65^{\circ} \mathrm{C}$ for $30 \mathrm{~min}$ in a washing buffer $\left(20 \mathrm{~mm} \mathrm{NaH}_{2} \mathrm{PO}_{4} \mathrm{pH}\right.$ 7.2 and $5 \mathrm{mg} \mathrm{ml}^{-1}$ SDS) and exposed to Kodak BioMax MS Film (Eastman Kodak Company, New Haven, CT, USA) at $-80^{\circ} \mathrm{C}$ for 2 days using BioMax TranScreen HE intensifying screen (Eastman Kodak Company).

\section{Expression studies}

Gene expression in human tissues of the isolated cDNA was determined by hybridising cDNA with the Multiple Tissue Expression Array (Clontech). Full-length coding cDNA was labelled with $\alpha-{ }^{32} \mathrm{P}$-dCTP, hybridised against the Multiple Tissue Expression Array and developed as described for Northern blots. In addition, rabbit PLP phosphatase antiserum (described above) diluted 1:500 was applied to the Newborn Rat Brain Protein Explorer (Alpha Diagnostic International, San Antonio, TX, USA), a commercial ready-made membrane containing brain proteins from rats. Hybridisations were detected using chemiluminescence following the instructions of the manufacturer, except that donkey anti-rabbit horseradish peroxidase-coupled IgG $(\mathrm{H}+\mathrm{L})$ (Jackson ImmunoResearch, West Grove, PA, USA) and the SuperSignal West Femto Maximum Sensitivity Substrate chemiluminescence kit (Pierce) were used for detection instead of the reagents in the kit. The membrane was exposed for $15 \mathrm{~min}$ on a IMAGE Station 2000R (Eastman Kodak Company).

\section{Statistical analysis}

Differences between groups were assessed using the Pearson $\chi^{2}$ test.

\section{Ethical considerations}

The study has been carried out with ethical committee approval. For animal experiments, United Kingdom co-ordinating committee on cancer research (UKCCCR) guidelines for the Welfare of Animals in Experimental Neoplasia were followed (Workman et al). The study was performed according to the Declaration of Helsinki.

\section{RESULTS}

\section{Identification of a novel autoantigen}

Screening the cDNA library with the PND serum revealed a positive clone that was isolated and sequenced. The nucleotide sequence showed that the clone was identical to a truncated form of PDXP that covered amino-acid codons 122-297 (GenBank accession number AY125047) (Fonda, 1992; Gao and Fonda, 1994a-c; Fonda and Zhang, 1995; Jang et al, 2003). Full-length cDNA for PDXP was ordered from the I.M.A.G.E Consortium and subcloned into the pET19b vector. The full-length coding sequence contained 891 nucleotides and encoded a protein of 297 amino acids with a molecular weight of $32 \mathrm{kDa}$.

\section{Expression of recombinant PDXP and production of antibodies against PDXP}

We expressed PDXP as ${ }^{35} \mathrm{~S}$-labelled protein using ITT (Figure 1A). The protein was also expressed in E. coli and purified to about $95 \%$ as judged by SDS-PAGE (Figure 1B). The molecular weight of the ITT-expressed protein correlated with the weight of the bacterially
A

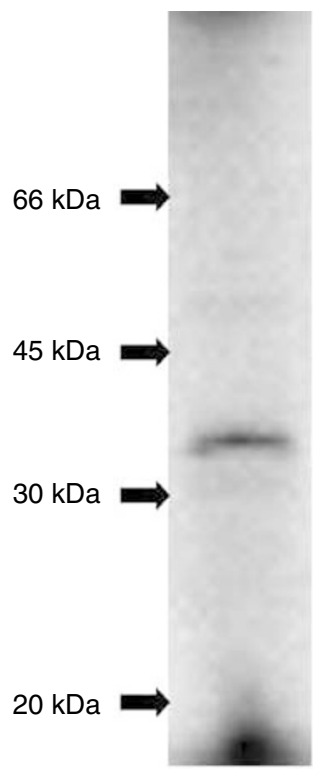

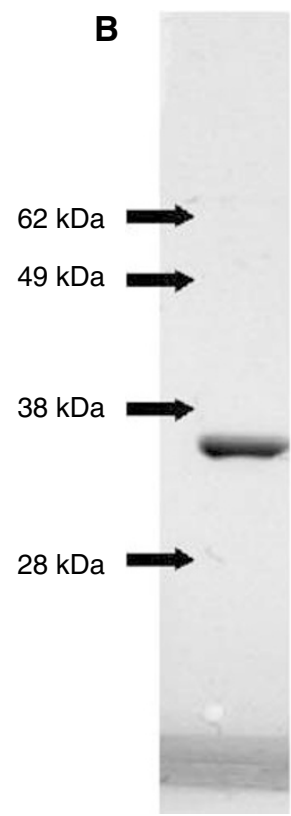

Figure I (A) SDS-PAGE of in vitro coupled transcribed and translated ${ }^{35}$ S-labelled PDXP. (B) SDS-PAGE of $2 \mu \mathrm{g}$ E. coli-expressed purified PDXP detected by Comassie blue staining.

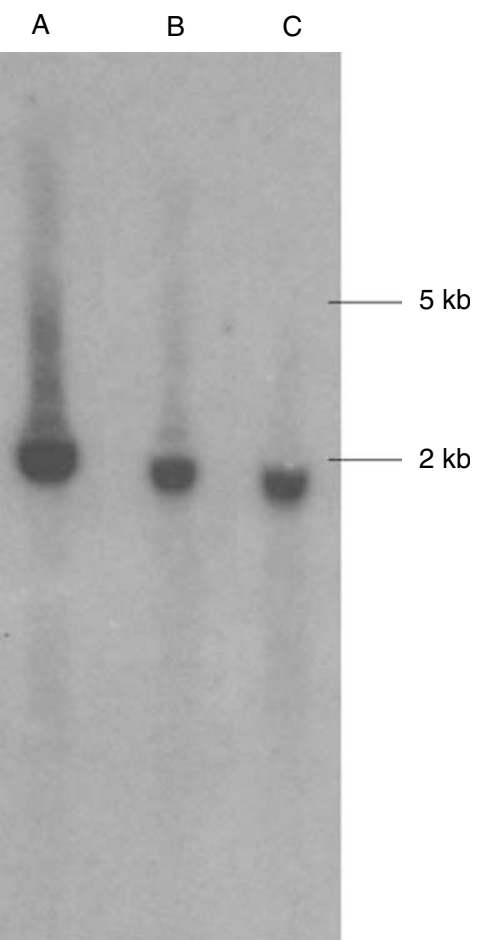

Figure 2 Northern blot of PDXP cDNA. The cDNA was labelled with $\alpha-{ }^{32} \mathrm{P}-\mathrm{dCTP}$ and hybridised against total RNA electrophoresed on a formaldehyde agarose gel. (A) Human reference total RNA. (B) Rat brain total RNA. (C) Rat cerebellar total RNA. 
expressed PDXP. Purified E. coli-expressed protein was used to immunise a rabbit in order to achieve antibodies against PDXP. One immunised rabbit produced a high-titre antiserum against PDXP as assessed by RIA and Western blot, whereas serum from the preimmunised rabbit did not bind the protein.

\section{Tissue expression of PDXP}

Northern blot of radioactive-labelled full-length PDXP against RNA pools of different origins revealed that the molecular weight of the messenger RNA was about $2 \mathrm{~kb}$ (Figure 2) (Jang et al, 2003). The results from mRNA multitissue expression level analysis of PDXP using polyA RNA dot blot indicated that the PDXP gene was strongly expressed in different parts of the central nervous system and also to some extent in testis, liver, kidney and cancer cell lines (Figure 3). Most of the other tissues represented on the blot also expressed PDXP but to a lesser degree than in the neuronal tissue. These results were supported by results obtained from analysis of the brain ReadyBlot explorer kit (data not shown).

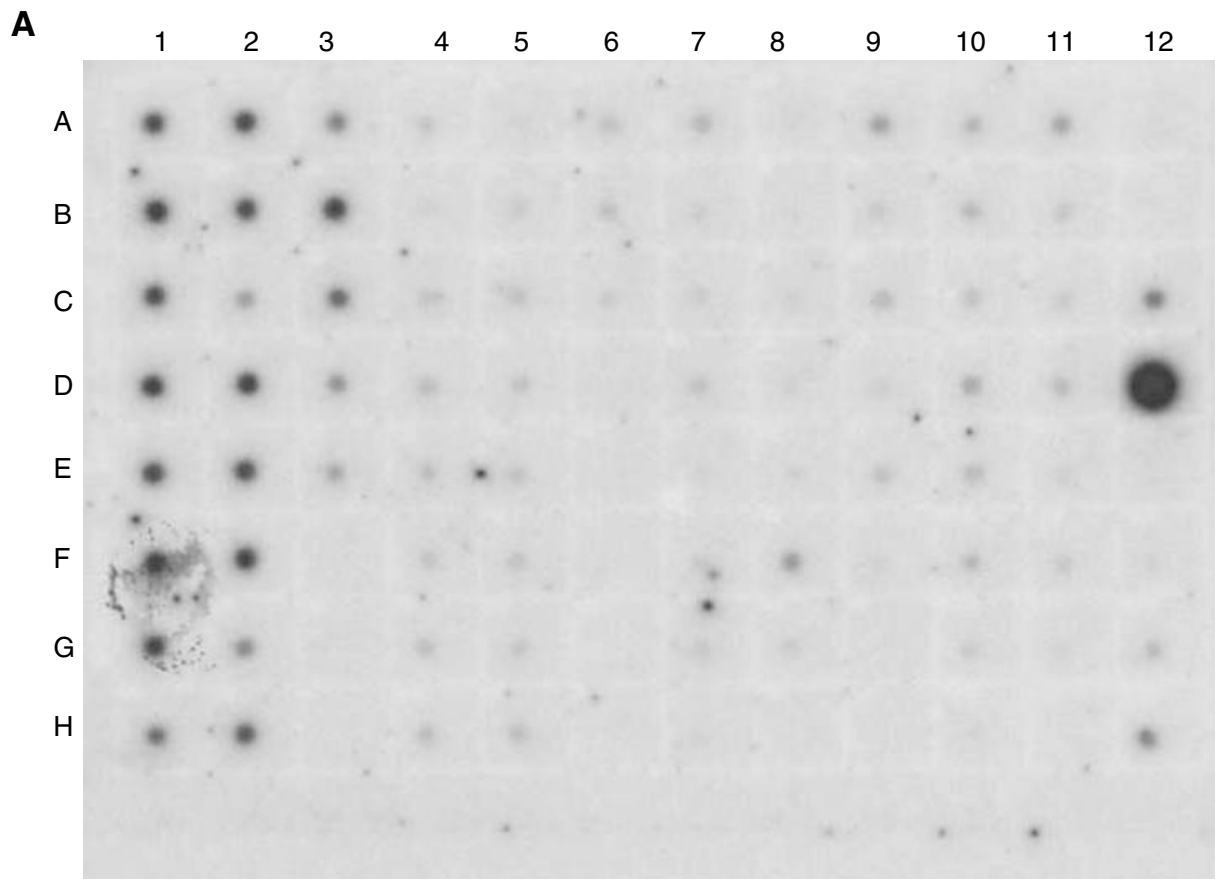

\begin{tabular}{|c|c|c|c|c|c|c|c|c|c|c|c|c|}
\hline B & 1 & 2 & 3 & 4 & 5 & 6 & 7 & 8 & 9 & 10 & 11 & 12 \\
\hline A & $\begin{array}{l}\text { Whole } \\
\text { brain }\end{array}$ & $\begin{array}{c}\text { Cerebellum, } \\
\text { left }\end{array}$ & $\begin{array}{c}\text { Substantia } \\
\text { nigra }\end{array}$ & Heart & Oesophagus & $\begin{array}{c}\text { Colon, } \\
\text { transverse }\end{array}$ & Kidney & Lung & Liver & $\begin{array}{c}\text { Leukaemia, } \\
\text { HL-60 }\end{array}$ & $\begin{array}{c}\text { Foetal } \\
\text { brain }\end{array}$ & $\begin{array}{c}\text { Yeast } \\
\text { total RNA }\end{array}$ \\
\hline B & $\begin{array}{l}\text { Cerebral } \\
\text { cortex }\end{array}$ & $\begin{array}{c}\text { Cerebellum, } \\
\text { right }\end{array}$ & $\begin{array}{c}\text { Nucleus } \\
\text { accumbens }\end{array}$ & Aorta & Stomach & $\begin{array}{c}\text { Colon, } \\
\text { desending }\end{array}$ & $\begin{array}{l}\text { Skeletal } \\
\text { muscle }\end{array}$ & Placenta & Pancreas & $\begin{array}{c}\text { HeLa } \\
\text { S3 }\end{array}$ & $\begin{array}{l}\text { Foetal } \\
\text { heart }\end{array}$ & $\begin{array}{l}\text { Yeast } \\
\text { tRNA }\end{array}$ \\
\hline C & $\begin{array}{c}\text { Frontal } \\
\text { lobe }\end{array}$ & $\begin{array}{l}\text { Corpus } \\
\text { callosum }\end{array}$ & Thalamus & $\begin{array}{c}\text { Atrium, } \\
\text { left }\end{array}$ & Duodenum & Rectum & Spleen & Bladder & $\begin{array}{l}\text { Adrenal } \\
\text { gland }\end{array}$ & $\begin{array}{c}\text { Leukaemia, } \\
\text { K-562 }\end{array}$ & $\begin{array}{l}\text { Foetal } \\
\text { kidney }\end{array}$ & $\begin{array}{l}\text { E. coli } \\
\text { rRNA }\end{array}$ \\
\hline D & $\begin{array}{l}\text { Parietal } \\
\text { lobe }\end{array}$ & Amygdala & $\begin{array}{l}\text { Pituitary } \\
\text { gland }\end{array}$ & $\begin{array}{l}\text { Atrium, } \\
\text { right }\end{array}$ & Jejunum & & Thymus & Uterus & $\begin{array}{l}\text { Thyroid } \\
\text { gland }\end{array}$ & $\begin{array}{c}\text { Leukaemia, } \\
\text { MOLT-4 }\end{array}$ & $\begin{array}{l}\text { Foetal } \\
\text { liver }\end{array}$ & $\begin{array}{l}\text { E. coli } \\
\text { DNA }\end{array}$ \\
\hline$E$ & $\begin{array}{l}\text { Occipital } \\
\text { lobe }\end{array}$ & $\begin{array}{l}\text { Caudate } \\
\text { nucleus }\end{array}$ & $\begin{array}{l}\text { Spinal } \\
\text { cord }\end{array}$ & $\begin{array}{c}\text { Ventricle, } \\
\text { left }\end{array}$ & Ileum & & $\begin{array}{l}\text { Peripheral } \\
\text { blood } \\
\text { leukocyte }\end{array}$ & Prostate & $\begin{array}{l}\text { Salivary } \\
\text { gland }\end{array}$ & $\begin{array}{c}\text { Burkitt's } \\
\text { lymphoma, } \\
\text { Raji }\end{array}$ & $\begin{array}{l}\text { Foetal } \\
\text { spleen }\end{array}$ & Poly $r(A)$ \\
\hline$F$ & $\begin{array}{c}\text { Temporal } \\
\text { lobe }\end{array}$ & $\begin{array}{l}\text { Hippo- } \\
\text { campus }\end{array}$ & & $\begin{array}{c}\text { Ventricle, } \\
\text { right }\end{array}$ & Ileocecum & & $\begin{array}{l}\text { Lymph } \\
\text { node }\end{array}$ & Testis & $\begin{array}{c}\text { Mammary } \\
\text { gland }\end{array}$ & $\begin{array}{c}\text { Burkitt's } \\
\text { lymphoma, } \\
\text { Daudi }\end{array}$ & $\begin{array}{l}\text { Foetal } \\
\text { thymus }\end{array}$ & $\begin{array}{c}\text { Human } \\
\mathrm{C}_{0} \mathrm{t}-1 \text { DNA }\end{array}$ \\
\hline $\mathrm{G}$ & $\begin{array}{l}\text { p.g. }{ }^{*} \text { of } \\
\text { cerebral } \\
\text { cortex }\end{array}$ & $\begin{array}{c}\text { Medulla } \\
\text { oblongata }\end{array}$ & & $\begin{array}{c}\text { Inter } \\
\text { ventricular } \\
\text { septum }\end{array}$ & Appendix & & $\begin{array}{l}\text { Bone } \\
\text { marrow }\end{array}$ & Ovary & & $\begin{array}{c}\text { Colorectal } \\
\text { adeno } \\
\text { carcinoma, } \\
\text { SW480 }\end{array}$ & $\begin{array}{l}\text { Foetal } \\
\text { lung }\end{array}$ & $\begin{array}{c}\text { Human } \\
\text { DNA } \\
100 \mathrm{ng}\end{array}$ \\
\hline $\mathrm{H}$ & Pons & Putamen & & $\begin{array}{l}\text { Apex of } \\
\text { the heart }\end{array}$ & $\begin{array}{c}\text { Colon, } \\
\text { ascending }\end{array}$ & & Trachea & & & $\begin{array}{l}\text { Lung } \\
\text { carcinoma, } \\
\text { A549 }\end{array}$ & & $\begin{array}{l}\text { Human } \\
\text { DNA } \\
500 \mathrm{ng}\end{array}$ \\
\hline
\end{tabular}

*Paracentral gyrus

Figure 3 Expression of PDXP in various human normal tissues and cancer cell lines. The PDXP cDNA was labelled with $\alpha_{-}{ }^{32} \mathrm{P}-\mathrm{dCTP}$ and hybridised against the Multiple Tissue Expression Array consisting of normalised, polyA RNA spotted on a nylon membrane as denoted in (B) PDXP transcripts are most abundant in the nervous system (columns I-3) (A). The cDNA probe hybridised with E. coli DNA, probably due to several identical nucleotide stretches. 


\section{Autoantibodies against PDXP in patients with cancer, autoimmune disease and controls}

Altogether, 22 of 243 (9.1\%) lung cancer patients and eight of 113 (7.1\%) patients with various other types of cancer had autoantibodies against PDXP (Figure 4), whereas two of $88(2.3 \%)$ sera from healthy controls revealed reactivity $(P=0.046$ when comparing all cancer patients with healthy controls). In addition, one of 47 (2.1\%) patients with type 1 diabetes (three of $72(4.1 \%)$ patients with autoimmune Addison's disease or APS and two of 47 (4.5\%) MS patients had autoantibodies against PDXP (Figure 4) $(P=0.008$ when comparing all four control groups with all cancer patients). Clinical data were only available from some of the cancer patients with PDXP antibodies, and no PND was discovered in these. Onconeuronal antibodies (anti-Hu) were detected in five of the anti-PDXP positive sera from the patients with lung cancer using immunofluorescence and immunoblot. None of the antibodypositive patients with Addison's disease, APS, diabetes or MS had known malignant disease. Among the patients with sera containing PDXP antibodies detected by RIA, five of $15(33 \%)$ patients with lung cancer and three of eight (38\%) patients with various types of cancer recognised PDXP by Western blot.

\section{Immunohistochemistry}

The rabbit antisera against PDXP stained human cerebrum and cerebellum but not liver, spleen, lung, heart, kidney and muscle (data not shown). Anti-PDXP stained the cytoplasm of microglia (Figure 5) and astrocytes. Neurons also stained weakly.

\section{DISCUSSION}

This study identified PDXP as a novel autoantigen associated with various types of cancer, including lung cancer. In total, $9 \%$ of patients with lung cancer and $7 \%$ of patients with other types of cancer revealed reactivity against PDXP vs 2\% among healthy controls. In the immunoprecipitation experiments, some sera reacted with native proteins and failed to recognise proteins that had been frozen (data not shown). This may imply that the protein changed its conformation after freezing and thawing and that autoantibodies recognise conformational epitopes. This speculation is supported by the finding that only a subgroup of the patients positive in the RIA assay showed reactivity in Western blot. RIA seems to be a more sensitive method for detecting autoantibodies, similar to the findings with anti-Hu (Storstein et al, 2004) and antiinsulin (Sodoyez-Goffaux et al, 1988). Five of the lung cancer patients positive for anti-PDXP also had circulating $\mathrm{Hu}$-antibodies but not clinically evident PND. Onconeuronal antibodies were not detected in any of the other anti-PDXP positive sera. Our findings therefore indicate that PDXP is associated with cancer and not with PND, but the latter association cannot be ruled out.

Autoantibodies against several different proteins are frequent in cancer patients, and most appear in a wide variety of types of

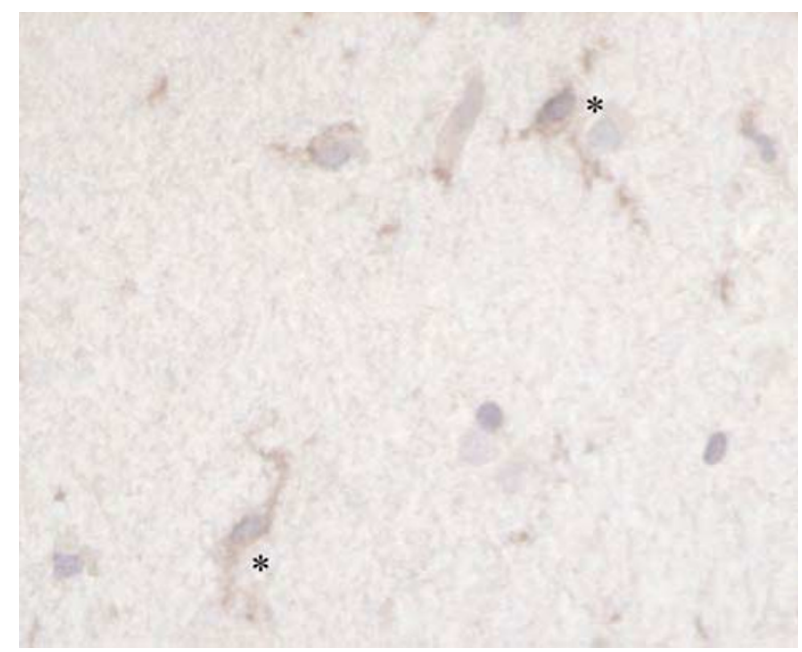

Figure 5 Anti-PDXP-stained cytoplasm of microglia of human brain sections in immunohistochemical experiments $(400 \times)$. Examples of stained cells are marked with *

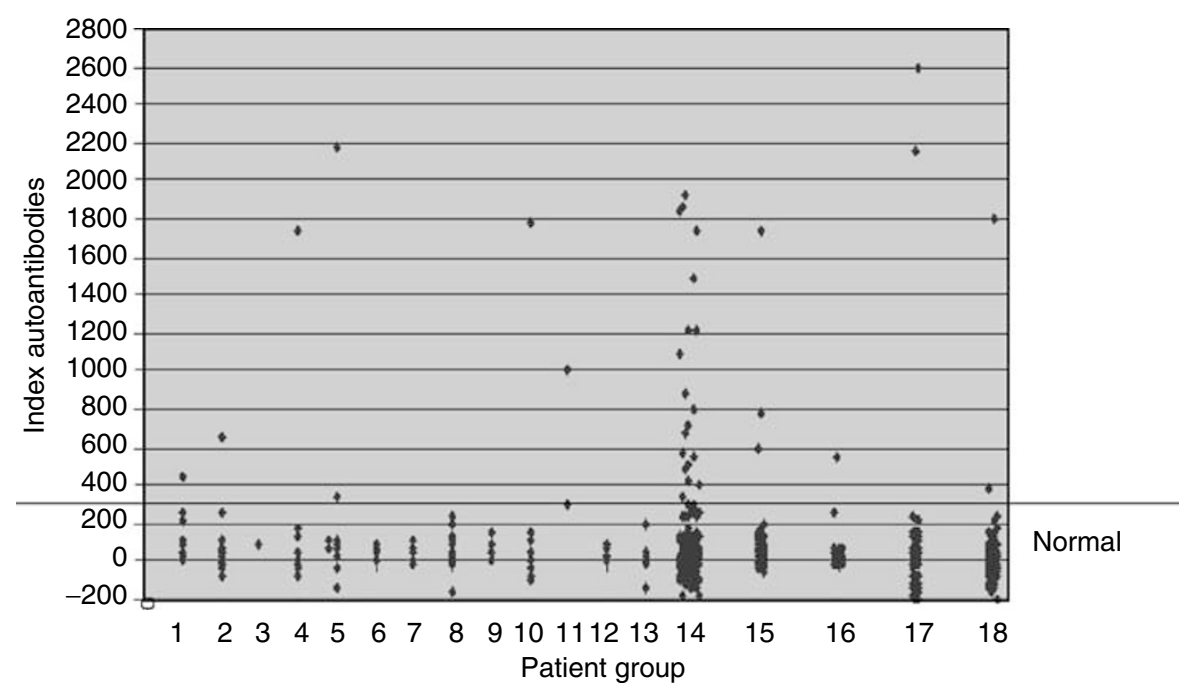

Figure 4 PDXP autoantibody analysis using immunoprecipitation assays. The figure shows the distribution of index values for the different groups of subjects used in this study. PDXP antibody reactivity is given as indices relative to a positive (patient serum) and negative control (pool of sera from healthy individuals) ((cpm subject $X-\mathrm{cpm}$ negative standard)/(cpm positive standard-cpm negative standard $) \times 1000)$. The cutoff value for identifying positive samples for autoantibodies against PDXP was 279. Lanes I - 14: sera from patients with tumours of different origins. I: lymphoma, 2: mammary, 3: bladder, 4: ovary, 5: uterus, 6: testis, 7: skin (malignant melanoma), 8: prostate, 9: kidney, I0: colon, I I: bile duct, I2: rectum, I 3: other, I4: lung. Lanes I5- I 8: sera from patients with other autoimmune diseases and controls. I5: Addison's disease or APS type II, 16: type I diabetes, 17: multiple sclerosis and I8: blood donors. 
cancer (Tan and Shi, 2003; Zhang et al, 2003), similar to our findings of anti-PDXP. Autoantibodies against the cell cycle checkpoint protein p53, for example, are found in $9-20 \%$ of human cancer patients with a specificity of $96 \%$ (Soussi, 2000). Hu and VGCC antibodies were not related to improved survival in patients with small-cell lung cancer (Monstad et al, 2004). The effects of circulating autoantibodies against PDXP are still unclear. Future studies on more well-defined patient materials should elucidate the sensitivity and specificity of the association between antibodies against PDXP and cancer. Our finding of an increased frequency among patients with Addison's disease, APS and MS compared with controls may imply other associations than cancer. It would also be interesting to determine whether anti-PDXP in patients affects the course and prognosis of malignant disease.

The recent study by Jang et al (2003) revealed that the expression of PDXP is ubiquitous, although with higher levels in the central nervous system, testis and liver. This is in agreement with our results. We found high expression in the central nervous system but also in a number of cancer cell lines, which could explain why PDXP becomes an autoantigen in patients with cancer. The PLP level in various tissues is regulated by several enzymes: PDXP, pyridoxal kinase, pyridoxamine-5'-phosphate oxidase and various binding proteins (Anderson et al, 1974; $\mathrm{Li}$ et al, 1974; Harris, 1990; Fonda, 1992). The brain contains an especially high concentration of PLP, and this is where the highest expression of PDXP is. More than 140 distinct enzymatic reactions depend on PLP according to the Enzyme Commission (http:// www.chem.qmul.ac.uk/iumbm/enzyme) (Percudani and Peracchi, 2003), including many enzymes that participate in the biosynthesis of important neurotransmitters. Examples of the latter are glutamate decarboxylase participating in the synthesis of GABA and aromatic L-amino acid decarboxylase participating in the biosynthesis of catecholamines and serotonin. Interestingly, these enzymes have recently been found to be autoantigens in nervous system and endocrine diseases. Antibodies against glutamate decarboxylase (Lindefors, 1993) are found in type 1 diabetes (Baekkeskov et al, 1990), stiff-man syndrome (Solimena et al, 1990) and APS type I (Velloso et al, 1994). Autoantibodies against aromatic L-amino acid decarboxylase (Rorsman et al, 1995), histidine decarboxylase (Skoldberg et al, 2003) and cysteine sulfinate decarboxylase (Skoldberg et al, 2004) are all found in patients with APS type I. We have now shown that another enzyme related to PLP is an autoantigen, making PLP a common denominator for enzymes targeted by the immune system in endocrine and nervous system autoimmune diseases.

The reason why the immune system recognises PDXP and other PLP-associated autoantigens as non-self remains obscure. PLP, which is the coenzymatically active form of vitamin $B_{6}$ (pyridoxine), is reported to suppress tumorigenesis, such as in colon cancer (Matsubara et al, 2003). The mechanisms behind the chemopreventive effect of vitamin $B_{6}$ probably combine inhibitory effects on cell proliferation, oxidative stress and angiogenesis. One theory is that some tumours express elevated levels of PDXP to overcome the suppressive effect of vitamin $\mathrm{B}_{6}$. The increased expression might induce a break in immune tolerance against PDXP. The Multiple Tissue Expression Array revealed that some cancer cell lines express PDXP. PLP has also recently been suggested to have immunomodulatory properties because it binds very tightly to the $\mathrm{D} 1$ domain of $\mathrm{CD} 4$ on $\mathrm{T}$ cells, thereby interfering with proper interaction between $\mathrm{CD} 4$ and the major histocompatibility complex class II (Salhany and Schopfer, 1993). Lack of interaction leads to T-cell apoptosis and anergy to autoantigens (Namazi, 2003). One might speculate increased expression of PDXP degrade PLP, thereby facilitating tumour growth, but this could also lead to an enhanced immune response against the tumour.

In conclusion, PDXP is a novel autoantigen associated with cancer. PLP seems to be a common denominator for autoantigens involved in nervous system and endocrine autoimmune diseases. The clinical implications of anti-PDXP remain to be defined.

\section{ACKNOWLEDGEMENTS}

Anette $\mathrm{B} ø \mathrm{e}$ is a fellow of the Research Council of Norway. We thank Mette Haugen, Department of Neurology, and Elin Theodorsen and Kristin Moen, Division of Endocrinology, Haukeland University Hospital, for excellent technical assistance. We also thank Lars $\mathrm{B} \varnothing$, Department of Neurology, Haukeland University Hospital, for help with immunohistochemical studies. We are indebted to Lars Drivsholm, Department of Oncology and Hematology, Næstved Hospital, Denmark, for providing sera from patients with lung cancer. The study was supported by grants from Innovest and Haukeland University Hospital.

\section{REFERENCES}

Anderson BB, Newmark PA, Rawlins M, Green R (1974) Plasma binding of vitamin $B_{6}$ compounds. Nature 250: $502-504$

Baekkeskov S, Aanstoot HJ, Christgau S, Reetz A, Solimena M, Cascalho M, Folli F, Richter-Olesen H, De Camilli P, Camilli PD (1990) Identification of the $64 \mathrm{~K}$ autoantigen in insulin-dependent diabetes as the GABAsynthesizing enzyme glutamic acid decarboxylase. Nature 347: 151-156

Bataller L, Dalmau J (2003) Paraneoplastic neurologic syndromes. Neurol Clin 21: $221-247$, ix

Cheever MA, Disis ML, Bernhard H, Gralow JR, Hand SL, Huseby ES, Qin HL, Takahashi M, Chen W (1995) Immunity to oncogenic proteins. Immunol Rev 145: 33-59

Covini G, Chan EK, Nishioka M, Morshed SA, Reed SI, Tan EM (1997) Immune response to cyclin B1 in hepatocellular carcinoma. Hepatology 25: $75-80$

Crawford LV, Pim DC, Bulbrook RD (1982) Detection of antibodies against the cellular protein $\mathrm{p} 53$ in sera from patients with breast cancer. Int $J$ Cancer 30: 403-408

Dalmau JO, Posner JB (1997) Paraneoplastic syndromes affecting the nervous system. Semin Oncol 24: 318-328

Falorni A, Nikoshkov A, Laureti S, Grenback E, Hulting AL, Casucci G, Santeusanio F, Brunetti P, Luthman H, Lernmark A (1995) High diagnostic accuracy for idiopathic Addison's disease with a sensitive radiobinding assay for autoantibodies against recombinant human 21hydroxylase. J Clin Endocrinol Metab 80: 2752 - 2755

Fonda ML (1992) Purification and characterization of vitamin $B_{6}$ phosphate phosphatase from human erythrocytes. J Biol Chem 267: $15978-15983$

Fonda ML, Zhang YN (1995) Kinetic mechanism and divalent metal activation of human erythrocyte pyridoxal phosphatase. Arch Biochem Biophys 320: $345-352$

Gao G, Fonda ML (1994a) Identification of an essential cysteine residue in pyridoxal phosphatase from human erythrocytes. J Biol Chem 269: 82348239

Gao GJ, Fonda ML (1994b) Evidence for a phosphoenzyme intermediate formed during catalysis by pyridoxal phosphatase from human erythrocytes. Arch Biochem Biophys 313: 166-172

Gao GJ, Fonda ML (1994c) Kinetic analysis and chemical modification of vitamin $\mathrm{B}_{6}$ phosphatase from human erythrocytes. J Biol Chem 269: $7163-7168$

Harris H (1990) The human alkaline phosphatases: what we know and what we don't know. Clin Chim Acta 186: 133-150

Jang YM, Kim DW, Kang TC, Won MH, Baek NI, Moon BJ, Choi SY, Kwon OS (2003) Human pyridoxal phosphatase: molecular cloning, functional expression and tissue distribution. J Biol Chem 278: 50040-50046 
Lang B, Newsom-Davis J, Wray D, Vincent A, Murray N (1981) Autoimmune aetiology for myasthenic (Eaton-Lambert) syndrome. Lancet 2: $224-226$

Li TK, Lumeng L, Veitch RL (1974) Regulation of pyridoxal 5'-phosphate metabolism in liver. Biochem Biophys Res Commun 61: 677-684

Lindefors N (1993) Dopaminergic regulation of glutamic acid decarboxylase mRNA expression and GABA release in the striatum: a review. Prog Neuropsychopharmacol Biol Psychiatry 17: 887-903

Matsubara K, Komatsu S, Oka T, Kato N (2003) Vitamin $\mathrm{B}_{6}$-mediated suppression of colon tumorigenesis, cell proliferation, and angiogenesis (review). J Nutr Biochem 14: 246-250

Monstad SE, Drivsholm L, Storstein A, Aarseth JH, Haugen M, Lang B, Vincent A, Vedeler CA (2004) Hu and voltage-gated calcium channel (VGCC) antibodies related to the prognosis of small-cell lung cancer. $J$ Clin Oncol 22: 795-800

Namazi MR (2003) Pyridoxal 5'-phosphate as a novel weapon against autoimmunity and transplant rejection. FASEB J 17: 2184-2186

Percudani R, Peracchi A (2003) A genomic overview of pyridoxalphosphate-dependent enzymes. EMBO Rep 4: 850-854

Rorsman F, Husebye ES, Winqvist O, Bjork E, Karlsson FA, Kampe O (1995) Aromatic-L-amino-acid decarboxylase, a pyridoxal phosphate-dependent enzyme, is a beta-cell autoantigen. Proc Natl Acad Sci USA 92: 8626-8629

Salhany JM, Schopfer LM (1993) Pyridoxal 5'-phosphate binds specifically to soluble CD4 protein, the HIV-1 receptor. Implications for AIDS therapy. J Biol Chem 268: $7643-7645$

Skoldberg F, Portela-Gomes GM, Grimelius L, Nilsson G, Perheentupa J, Betterle C, Husebye ES, Gustafsson J, Ronnblom A, Rorsman F, Kampe O (2003) Histidine decarboxylase, a pyridoxal phosphate-dependent enzyme, is an autoantigen of gastric enterochromaffin-like cells. J Clin Endocrinol Metab 88: 1445 - 1452

Skoldberg F, Rorsman F, Perheentupa J, Landin-Olsson M, Husebye ES, Gustafsson J, Husebye ES, Kampe O (2004) Analysis of antibody reactivity against cysteine sulfinic acid decarboxylase, a pyridoxal phosphate-dependent enzyme, in endocrine autoimmune disease. J Clin Endocrinol Metab 89: 1636-1640

Sodoyez-Goffaux F, Koch M, Dozio N, Brandenburg D, Sodoyez JC (1988) Advantages and pitfalls of radioimmune and enzyme linked immunosorbent assays of insulin antibodies. Diabetologia 31: 694-702
Solimena M, Folli F, Aparisi R, Pozza G, De Camilli P (1990) Autoantibodies to GABA-ergic neurons and pancreatic beta cells in stiff-man syndrome. $N$ Engl J Med 322: $1555-1560$

Soussi T (2000) p53 Antibodies in the sera of patients with various types of cancer: a review. Cancer Res 60: $1777-1788$

Souza SL, Montalli Da Assumpcao LV, Ward LS (2003) Impact of previous thyroid autoimmune diseases on prognosis of patients with welldifferentiated thyroid cancer. Thyroid 13: $491-495$

Storstein A, Monstad SE, Nakkestad HL, Husebye ES, Vedeler CA (2004) Paraneoplastic antibodies against $\mathrm{HuD}$ detected by a sensitive radiobinding assay. J Neurol 251: $197-203$

Tan EM, Shi FD (2003) Relative paradigms between autoantibodies in lupus and autoantibodies in cancer. Clin Exp Immunol 134: 169-177

Trivers GE, Cawley HL, DeBenedetti VM, Hollstein M, Marion MJ, Bennett WP, Hoover ML, Prives CC, Tamburro CC, Harris CC (1995) Anti-p53 antibodies in sera of workers occupationally exposed to vinyl chloride. J Natl Cancer Inst 87: 1400-1407

Trivers GE, De Benedetti VM, Cawley HL, Caron G, Harrington AM, Bennett WP, Jett JR, Colby TV, Tazelaar H, Pairolero P, Miller RD, Harris CC (1996) Anti-p53 antibodies in sera from patients with chronic obstructive pulmonary disease can predate a diagnosis of cancer. Clin Cancer Res 2: $1767-1775$

Velloso LA, Winqvist O, Gustafsson J, Kampe O, Karlsson FA (1994) Autoantibodies against a novel $51 \mathrm{kDa}$ islet antigen and glutamate decarboxylase isoforms in autoimmune polyendocrine syndrome type I. Diabetologia 37: $61-69$

Workman P, Twentyman P, Balkwill F, Balmain A, Chaplin D, Double J, Embleton J, Newell D, Raymond R, Stables J, Stephens T, Wallace J. United Kingdom co-ordinating committee on cancer research (UKCCCR) guidelines for the Welfare of Animals in Experimental Neoplasia

Zhang JY, Casiano CA, Peng XX, Koziol JA, Chan EK, Tan EM (2003) Enhancement of antibody detection in cancer using panel of recombinant tumor-associated antigens. Cancer Epidemiol Biomarkers Prev 12: $136-143$

Zhang JY, Chan EK, Peng XX, Tan EM (1999) A novel cytoplasmic protein with RNA-binding motifs is an autoantigen in human hepatocellular carcinoma. J Exp Med 189: $1101-1110$ 